\title{
DERADIKALISASI ISLAM MELALUI PENDIDIKAN MULTIKULTURAL BERBASIS KEARIFAN LOKAL PADA MASYARAKAT CIGUGUR
}

\author{
Muhamad Arif \\ Universitas Islam Negeri Syarif Hidayatullah Jakarta \\ Jl. Ir. H. Djuanda No. 95, Tangerang, 15412, Indonesia \\ E-mail:arifia555@yahoo.co.id
}

\begin{tabular}{l|l|l}
\hline Received: & Revised: & Approved: \\
18/03/2017 & $08 / 06 / 2017$ & $22 / 06 / 2017$ \\
\hline
\end{tabular}

\section{Abstrak}

Artikel ini bertujuan untuk mendeskripsikan konteks deradikalisasi Islam melalui pendidikan multikultural berbasis kearifan lokal. Untuk maksud tersebut, dilakukan penelitian mendalam pada masyarakat Cigugur. Penelitian menghasilkan temuan bahwa sikap toleran, saling menghargai, saling menghormati, dan bahkan saling bekerja sama yang tercipta dalam kehidupan masyarakat Cigugur yang multi agama dan multikultural didukung oleh aktualisasi pendidikan multikultural berbasis kearifan lokal yang mencakup tiga dimensi, yakni dimensi waktu, dimensi tempat, dan dimensi isi. Menurut dimensi waktu, pendidikan diselenggarakan dalam tiga fase, yakni sateuacan nitis (sebelum nitis), sateuacan boboran (sebelum lahir), dan saatosna boboran (setelah lahir). Menurut dimensi tempat, masyarakat Cigugur menyelenggarakan pendidikan di lingkungan keluarga (pendidikan informal), lingkungan sekolah (pendidikan formal), dan lingkungan 
masyarakat (pendidikan nonformal). Sementara, menurut dimensi isi, terdapat etika sebagai pedoman dan tuntunan berperilaku sosial yakni berupa cara ciri manusia dan cara ciri bangsa.

Kata kunci: Pendidikan, multikultural, dan kearifan lokal.

\section{Abstract}

This article aims to describe the context of the de-radicalization of Islam through multicultural education based on local wisdom. For this purpose, conducted in-depth research on Cigugur society. The study produced findings that tolerance, mutual respect, and even cooperate with each other in Cigugur society that's multireligious and multicultural, supported by the actualization of multicultural education based on local wisdom that includes three dimensions, namely the dimension of time, the dimensions of the place, and dimensional content. According to the dimension of time, education was held in three phases, namely "sateuacan nitis" (before mariage), "sateuacan boboran" (before birth), and "saatosna boboran" (after birth). According to the dimensions of the place, the people Cigugur education in the family environment (informal education), school environment (formal education) and community (non-formal education). Meanwhile, according to the dimensions of the content, there are ethical guidelines and guidance in social behavior, namely "cara ciri manusia" and "cara-ciri bangsa".

Keywords: Education, Multicultural, and local knowledge.

\section{A. Pendahuluan}

Radikalisme -tidak terkecuali yang dimotori oleh pemahaman agama tertentu- bisa terjadi di belahan dunia manapun. Sejarah telah mencatat, nyaris di sepanjang waktu, di belahan dunia Barat dan Timur tidak pernah sepi 
dari aksi radikalisme. Dalam konteks ini, radikalisme dapat dikatakan sebagai suatu gerakan yang berpandangan kolot dan sering menggunakan kekerasan dalam mengajarkan keyakinan mereka. ${ }^{1}$ Dalam konteks keislaman dan keindonesiaan, gerakan radikalisme, tentu saja, sangat kontras dengan pemahaman jumhur. Mengapa demikian?

Melihat Indonesia, terutama dalam sudut pandang historis dan kultural, adalah melihat bangsa yang besar, lengkap dengan entitas budaya yang multikultural. Dalam perjalanan sejarahnya, Indonesia merupakan bangsa yang ramah terhadap berbagai unsur budaya sehingga tidak berlebihan jika dikatakan bahwa Indonesia merupakan hasil dari proses akulturasi yang panjang dan kompleks sehingga berbagai unsur budaya dunia, yakni budaya India, Cina, dan Islam telah bertemu padu sedemikian rupa sehingga membentuk sebuah budaya baru bernama budaya Indonesia. Secara substantif, fenomena pembentukan budaya Indonesia seperti itu sungguh berseberangan dengan fenomena radikalisasi yang marak pasca jatuhnya regim Orde Baru pada tanggal 21 Mei 1998. Bahwa bersamaan dengan berkembangnya era demokratisasi berikut hiruk-pikuk eforia kebebasan itu, secara tidak langsung telah memfasilitasi munculnya beberapa kelompok radikal yang lebih visible dan lebih militan. ${ }^{2}$ Indonesia yang ramah -dan selama ini telah disemarakkan oleh nuansa Islam yang damai-seolah ternoda oleh berbagai aksi teror yang ditengarai sebagai salah satu wujud dari radikalisme Islam. Maka, artikel ini ditulis guna mengurai jawab atas beberapa pertanyaan menyangkut: radikalisme Islam, faktor-faktor pendorong radikalisme

1 Harun Nasution, Islam Rasional (Bandung: Mizan Media Utama, 1995), 124.

2 Azumardi Azra, "Radikalisme Islam Indonesia," Tempo, 15 Desember 2002. 
Islam, konsep dan praktik pendidikan multikulturalisme, berikut peranannya bagi proses deradikalisasi Islam di Indonesia.

\section{B. Radikalisme Islam dan Faktor Pendorongnya}

Pada dasarnya, kekerasan yang mengatasnamakan agama bisa terjadi di mana saja dan kapan saja, baik yang melibatkan umat Islam maupun nonmuslim. Artinya, radikalisme keagamaan sebenarnya fenomena yang biasa muncul dalam agama apa saja. ${ }^{3}$ Kekerasan atas nama agama merupakan wujud radikalisme. Sementara radikalisme rentan berkembang jika agama -sebagai dasarnyadipahami secara sempit, kaku, dan fanatik. Dalam hal ini Ernest Gellner menjelaskan bahwa radikalisme terjadi karena suatu agama dipegang kuat secara literal, tanpa kompromi, pelenturan, reintepretasi maupun pengurangan. ${ }^{4}$ Pemahaman agama seperti inilah yang rentan bagi berkembangnya radikalisme, sebab, setiap saat bisa meletus dalam bentuk kekerasan manakala terdapat kekuatan luar yang dianggap mengganggu dan/atau mengancam keberadaannya. Maka, penting untuk digarisbawahi bahwa radikalisme Islam tidak boleh secara serampangan dipandang sebagai bagian dari substansi ajaran Islam.

Radikalisme merupakan gerakan yang berpandangan kolot dan sering menggunakan kekerasan dalam mengajarkan keyakinan mereka. ${ }^{5}$ Sementara, Mohammed Arkoun menjelaskan bahwa radikalisme terjadi akibat

3 Endang Turmudi, ed., Islam dan Radikalisme di Indonesia (Jakarta: LIPI Press, 2005), 85-86.

4 Azyumardi Azra, Pergolakan Politik Islam; dari Fundamentalisme, Modernisme hingga Post-Modernisme (Jakarta: Paramadina, 1996), 108.

${ }^{5}$ Nasution, Islam Rasional, 124. 
pemahaman tekstual atas pesan yang disampaikan oleh AlQur'an yang berbeda-beda yang berkembang seiring dengan kondisi lingkungan dan faktor-faktor lain di mana individu berada. ${ }^{6}$ Dalam hal ini, Mohammed Arkoun melihat radikalisme Islam yang tak terpisahkan dari fenomena politis dan sekaligus ideologis. ${ }^{7}$ Bahwa radikalisme Islam muncul sebagai akibat dari gerakan politis kelompok tertentu dengan kepentingan tertentu pula. Di samping itu, radikalisme Islam rentan terjadi manakala secara ideologis Islam disalahpahami secara sempit, kaku, dan fanatik, karena memudahkan bagi kekuatan politis tertentu untuk menyusupkan agenagennya yang provokatif guna mengusung kepentingan tertentu. Radikalisme Islam di Indonesia tak kurang dari realitas politis dan ideologis seperti itu. ${ }^{8}$

Tiga kecenderungan yang menjadi indikasi radikalisme. Pertama, radikalisme merupakan respons penolakan terhadap kondisi yang sedang berlangsung, baik berupa asumsi, ide, lembaga, atau nilai-nilai tertentu. Kedua, radikalisme bisa meningkat menjadi upaya mengganti suatu asumsi, ide, lembaga, atau nilai-nilai tertentu. Kecenderungan seperti ini menunjukan bahwa di dalam radikalisme terkandung suatu asumsi, ide, lembaga, atau nilai-nilai tersendiri. Ketiga, radikalisme cenderung terjadi karena kuatnya keyakinan kaum radikalis akan kebenaran sistem ideologi yang dianut, sementara pada saat yang sama dibarengi dengan panafian terhadap kebenaran sistem ideologi lain. Kuatnya keyakinan itulah yang

6 Listiyono Santoso, Seri Pemikiran Tokoh Epistimologi Kiri (Jakarta: Ar-Ruzz Media, 2010), 199.

7 Mohammed Arkoun, Islam Kontemporer menuju Dialog Antaragama (Yogyakarta: Pustaka Pelajar, 2001).

8 M. Zaki Mubarak, Geneologi Islam Radikal di Indonesia (Jakarta: LP3ES, 2008). 
memicu sikap fanatis yang pada gilirannya akan mengakibatkan munculnya sikap emosional di kalangan kaum radikalis. ${ }^{9}$

Pandangan di atas dapat digunakan untuk menganalisis gerakan-gerakan keagamaan Islam yang secara endemik telah berkembang pada masa reformasi. Sejak era reformasi, ekspresi gerakan keagamaan tampak lebih lugas dan tegas, lengkap dengan berbagai konsep yang berkaitan dengan implementasi ajaran Islam dalam kehidupan bernegara. ${ }^{10}$ Tentu saja fenomena seperti ini tak kurang sebagai sebuah penolakan terhadap peri kehidupan bernegara yang didominasi oleh sistem demokrasi ala Barat yang liberal, sehingga memicu sebagian kalangan Islam untuk melakukan formalisasi syari'at Islam melalui keputusan politik formal, dengan penerapan hukum Islam secara keseluruhan, yakni menyangkut aspek jinayah atau hudud. ${ }^{11}$ Artinya, sebagian kalangan Islam tidak puas terhadap penerapan syari'at Islam yang tidak total, sehingga dipandang perlu untuk memberlakukan syari'at secara kaffah (menyeluruh) sesuai dengan pandangan mereka.

Sementara, Azyumardi Azra menguraikan tiga faktor penyebab munculnya gerakan radikalisme keagamaan, yakni ditinjau dari: (1) variabel norma dan ajaran, (2) variabel sikap atau pemahaman mengenai tiga isu penerapan syariat Islam, bentuk negara Islam Indonesia, dan Khalifah Islamiyah, serta (3) variabel sikap yang

9 Tarmizi Taher, et.all, Radikalisme Agama (Jakarta: PPIM IAIN Syarif Hidayatullah, n.d.), xvii-xviii.

${ }^{10}$ Muhammad Hisyam, dkk, Islam dan Radikalisme di Indonesia (Jakarta: LIPI Press, 2005), 120.

${ }^{11}$ Ibid., 123. 
muncul ketika variabel kedua dihadapkan dengan kondisi sosial nyata dalam masyarakat. ${ }^{12}$

Pertama, variabel norma dan ajaran, Bahwa norma dan ajaran yang menjadi dasar perilaku bersumber dari AlQur'an, Hadis, sebagian juga Ijma Ulama. Bahwa setiap anggota masyarakat muslim mengalami sosialisasi primer, pengalaman, pendidikan, dan level sosial-ekonomi yang berbeda, sehingga memungkinkan bagi interpretasi terhadap ajaran dan norma berbeda. Hasil interpretasi tersebut terus-menerus mengalami proses internalisasi sehingga menjadi standar pandangan dan perilaku yang bersifat menetap, salah satunya menyangkut apa yang diidealkan berkaitan dengan kehidupan masyarakat Islam. Kedua, variabel sikap atau pemahaman mengenai tiga isu penerapan syariat Islam, bentuk Negara Islam Indonesia, dan Khalifah Islamiyah. Sikap ini merupakan kelanjutan dari penafsiran terhadap ajaran agama Islam. Diasumsikan terdapat tiga sikap umum yang tersimbolkan dalam penerapan pemahaman Muslim terhadap ajaran agama mereka, yakni: sekuler atau nisbi, substansialis, dan skriptualis. Ketiga, variabel sikap yang muncul ketika variabel kedua dihadapkan dengan kondisi sosial nyata dalam masyarakat, termasuk faktor-faktor yang bersifat domestik maupun internasional. Hegomoni politik oleh negara atau represi yang dilakukan oleh kelompok apapun terhadap umat Islam akan melahirkan respon yang berbeda-beda. Kalangan sekuler (nisbi) sama sekali tidak merespon karena mereka benar-benar indifferent. Kelompok skriptualis diasumsikan akan memperlihatkan sikap yang radikal. Sementara, kelompok substansialis, meskipun punya kepedulian terhadap Islam dan juga umatnya dalam

${ }^{12}$ Azra, “Radikalisme Islam Indonesia.” 
berbagai bidang, tetapi cenderung memperlihatkan sikap moderat. ${ }^{13}$

Belakangan ini, radikalisme Islam, baik dalam skala lokal maupun global, terlihat semakin masif. Kebijakan represif yang dilakukan oleh pemerintah -dengan tekanan kepentingan asing-justru kontraproduktif. Radikalisme Islam tidak akan berkurang dengan cara-cara represif seperti itu, bahkan semakin subur seperti jamur di musim penghujan. Dalam hal ini, perlu dipikirkan pendekatan lain yang lebih manusiawi sekaligus mencerminkan karakteristik Indonesia, yakni tindakan preventif yang salah satunya melalui pendidikan multikultural berbasis kearifan lokal.

\section{Deradikalisasi Islam melalui Pendidikan Multikultural Berbasis Kearifan Lokal \\ 1. Konsep Pendidikan Multikultural}

Andersen dan Cusher mendefinisikan pendidikan multikultural sebagai pendidikan mengenai keragaman kebudayaan. ${ }^{14}$ Bahwa keragaman kebudayaan merupakan realitas tak terbantah yang ada pada suatu komunitas dan konsekuensinya perlu dipelajari oleh setiap anggota komunitas guna menciptakan harmoni sosial. Sementara, James Banks mendefinisikan pendidikan multikultural sebagai pendidikan untuk people of color. ${ }^{15}$ Bahwa perbedaan merupakan sebuah keniscayaan sehingga perlu dipertahankan sebagaimana adanya untuk saling melengkapi dan saling menyempurnakan. Masih menurut Banks, pendidikan multikultural merupakan suatu rangkaian kepercayaan yang mengakui pentingnya

${ }^{13}$ Ibid.

14 Choirul Mahfud, Pendidikan Multikultural (Yogyakarta: Pustaka Pelajar, 2006), 175.

${ }^{15}$ Mahfud, Pendidikan Multikultural. 
keragaman budaya dan etnis dalam bentuk gaya hidup, pengalaman sosial, identitas pribadi, kesempatan pendidikan dari individu, kelompok maupun negara. ${ }^{16}$

Secara konsepsional, Tilaar menjelaskan bahwa konstruksi pendidikan multikultural perlu memperhatikan tiga komponen yang saling berkaitan. Pertama, komponen kebudayaan, yakni berbagai hal yang menyangkut identitas budaya suatu kelompok masyarakat. Kedua, komponen tradisi, yakni pola perilaku dan kebiasaan yang hidup di dalam suatu masyarakat. Ketiga, komponen kemajuan (achievement) sebagai suatu pencapaian dalam kehidupan masyarakat yang memberikan identitas baru yang melekat pada suatu kelompok masyarakat. ${ }^{17}$

Pada dasarnya, konsep pendidikan multikultural yang dikembangkan oleh Tilaar mengacu pada konsep C.I. Bennet yang menunjukkan dua aspek mendasar, yaitu nilai inti dan tujuan pendidikan multikultural. Nilai-nilai inti pendidikan multikultural mencakup: (1) apresiasi terhadap keragaman budaya yang terdapat dalam kehidupan masyarakat, (2) pengakuan terhadap kesamaan harkat, martabat, dan hak asasi manusia, (3) penanaman rasa tanggung jawab manusia terhadap keragaman budaya pada masyarakat dunia, dan (4) pengembangan tanggung jawab manusia terhadap planet bumi. ${ }^{18}$ Berdasarkan nilai inti tersebut, dirumuskan beberapa tujuan dari pendidikan multikultural, yaitu: (1) untuk mengembangkan perspektif sejarah yang beragam dari kelompok-kelompok

16 James A. Banks, An Introduction to Multicultural Education (Boston: Allyn and Bacon, 1993).

17 H.A.R Tilaar, Kekuasaan dan Pendidikan: Manajemen Pendidikan Nasional dalam Pusaran Kekuasaan (Jakarta: Rineka Cipta, 2009), 207.

18 Dody S. Taruna, Pendidikan Agama Islam Berwawasan Multikulturalisme (Jakarta: Kementrian Agama RI, 2010), 107. 
masyarakat, (2) untuk memperkuat kesadaran budaya yang hidup di masyarakat, (3) untuk memperkuat kompetensi interkultural dari budaya-budaya yang hidup di masyarakat, (4) untuk membasmi rasisme, seksisme, dan berbagai jenis prasangka, (5) untuk mengembangkan kesadaran atas kepemilikan planet bumi, dan (6) untuk mengembangkan ketrampilan aksi sosial.19 Dengan demikian, pendidikan multikultural merupakan respon atas ancaman disintegrasi bangsa dan dominasi sekelompok masyarakat tertentu terhadap kelompok masyarakat yang lain.

\section{Implementasi Pendidikan Multikultural}

Secara implementatif, pendidikan multikultural diselenggarakan dengan menggunakan metode dan pendekatan yang beragam. Marlina Annisa Dewi menjelaskan empat metode yang dapat digunakan dalam pendidikan multikultural, yakni: (1) metode kontribusi, (2) metode pengayaan, (3) metode transformatif, serta (4) metode pembuatan keputusan dan aksi sosial.

Pendidikan multikultural dapat diselenggarakan melalui berbagai macam pendekatan. Adapun pendekatan yang mungkin dapat dilakukan dalam penyelenggaraan pendidikan multikultural adalah pendekatan historis, pendekatan sosiologis, pendekatan kultural, pendekatan psikologis, pendekatan estetik, dan pendekatan berperspektif gender.

Pendekatan historis, yakni materi pendidikan direfleksikan dengan menengok kembali peristiwa sejarah pada masa lampau. Maksudnya agar pembelajar mempunyai kerangka berpikir yang komplit didasarkan

19 H.A.R. Tilaar, Kukuasaan dan Pendidikan: Manajemen Pendidikan Nasional dalam Pusaran Kekuasaan (Jakarta: Rineka Cipta, 2009), 210. 
pada peristiwa sejarah pada masa lampau untuk kemudian direfleksikan pada kehidupan pada masa sekarang dan masa yang akan datang. Melalui pendekatan historis seperti ini, materi yang diajarkan dapat dianalisis secara kritis.

Pendekatan sosiologis, yakni pendekatan yang mengandaikan terjadinya proses kontekstualisasi atas apa yang pernah terjadi pada masa lampau. Melalui pendekatan ini materi pembelajaran menjadi aktual, bukan karena dibuat-buat melainkan karena senantiasa sesuai dengan perkembangan zaman. Pendekatan ini tidak bersifat indoktrinisasi karena kerangka berpikir yang dibangun adalah kerangka berpikir kekinian. Pendekatan ini bisa digabungkan dengan metode pengayaan.

Pendekatan kultural, yakni pendekatan yang menitikberatkan pada otentisitas dan tradisi yang berkembang. Melalui pendekatan ini pembelajar dapat melihat mana tradisi yang otentik dan mana yang tidak, mana mana tradisi Arab dan mana tradisi yang datang dari Islam.

Pendekatan psikologis, yakni pedekatan yang berusaha memperhatikan situasi psikologis perseorangan secara tersendiri dan mandiri. Artinya, masing-masing pembelajar harus dilihat sebagai manusia mandiri dengan karakter dan kemampuan yang dimilikinya.

Pendekatan estetik, yakni pendekatan estetik yang mengajarkan pembelajar untuk berlaku sopan, santun, damai, ramah, dan mencintai keindahan. Sebab segala materi kalau hanya didekati secara doktrinal dan menekan adanya otoritas-otoritas kebenaran maka pembelajar akan cenderung bersikap kasar. Pendekatan ini diperlukan untuk mengapresiasikan segala gejala yang terjadi di masyarakat dengan melihat gejala tersebut sebagai bagian dari dinamika kehidupan yang bernilai seni dan estetis.

Pendekatan berperspektif gender, yakni pendekatan yang mecoba memberikan penyadaran kepada pembelajar 
untuk tidak membedakan jenis kelamin karena sebenarnya jenis kelamin bukanlah hal yang menghalangi seseorang untuk mencapai kesuksesan. Dengan pendekatan ini, segala bentuk konstruksi sosial yang ada di sekolah yang menyatakan bahwa perempuan berada di bawah laki-laki bisa dihilangkan. ${ }^{20}$

\section{Konsep Kearifan Lokal}

Kearifan lokal terdiri dari dua kata, kearifan dan lokal. Kearifan berarti kemampuan seseorang dalam menggunakan akal pikiran untuk menyikapi sesuatu kejadian, obyek, atau situasi. Sedangkan lokal, menunjukkan ruang interaksi sehingga menumbulkan suatu peristiwa. Secara substansial, kearifan lokal merupakan nilai dan norma yang berlaku dalam suatu masyarakat yang diyakini kebenarannya dan menjadi acuan dalam bertindak dan berperilaku sehari-hari. Kearifan lokal merupakan kecerdasan manusia yang dimiliki oleh kelompok etnis tertentu yang diperoleh melalui pengalaman masyarakat. ${ }^{21}$ Definisi ini menunjukkan bahwa kearifan lokal merupakan hasil budi dan daya dari masyarakat tertentu melalui pengalaman hidup yang khas dan panjang sehingga mengkristalkan nilai-nilai yang melekat kuat pada masyarakat tertentu yang tidak dimiliki oleh masyarakat yang lain. ${ }^{22}$ Oleh karena itu, kearifan lokal merupakan entitas yang sangat

20 James A Banks dan Cherry A. McGee Banks, "Multicultural Education: Historical Development, Dimensions, and Practice," in Handbook of Research on Multicultural Education, n.d., 12-13.

21 F. X. Rahyono, Kearifan Budaya dalam Kata (Jakarta: Wedatama Widyasastra, 2009).

22 Nurma Ali Ridwan, "Landasan Keilmuan Kearifan Lokal.," Ibda: Jurnal Studi Islam dan Budaya P3M STAIN Purwokerto 5, no. 1 (Juni 2007). 
menentukan harkat dan martabat manusia dalam komunitasnya. ${ }^{23}$

Kearifan lokal lazim dikonsepsikan sebagai kebijakan setempat (local wisdom), pengetahuan setempat (local knowledge), atau kecerdasan setempat (local genius). Dalam konteks ini, kearifan lokal merupakan sikap, pandangan, dan kemampuan suatu masyarakat dalam mengelola lingkungan yang memberikan daya tahan dan daya tumbuh suatu masyarakat di wilayah di mana masyarakat itu berada. Dengan kata lain, kearifan lokal adalah jawaban kreatif terhadap segala fenomena yang terdapat di lingkungan sekitar. ${ }^{24}$

Dalam pengertian yang lebih luas, kearifan lokal dapat dipahami sebagai berikut: "Local wisdom is the knowledge that discovered or acquired by local people through the accumulation of experiences in trials and integrated with the understanding of surrounding nature and culture."25 Bahwa kearifan lokal merupakan pengetahuan yang terakumulasi karena pengalaman-pengalaman hidup yang dipelajari dari berbagai situasi di sekeliling kehidupan manusia dalam suatu wilayah. Dengan demikian, kearifan lokal merupakan pengetahuan yang dikembangkan oleh generasi terdahulu dalam berinteraksi dengan lingkungan sekitar, untuk kemudian pengetahuan tersebut menjadi bagian dari budaya yang diwariskan kepada generasi-generasi berikutnya. Dengan kata lain, merupakan produk budaya

23 Roland Robertson, "Religion in Java: Conflict and Integration," in Sociology of Religion: Selected Readings (England: Penguine Book, 1971), 165-217.

${ }^{24}$ Saini K.M, "Kearifan Lokal di Arus Global," Pikiran Rakyat, 30 Juli 2005.

25 Chatcharee Naritoom, "Local Wisdom/Indigenous Knowledge System" (Kasetsart University, Thailand, 18 Maret 2015), http://pimd.iwmi.org/Library/pdf/PPT 6 Indigeneous Knowledge Systems.ppt. 
masa lalu yang secara terus-menerus dijadikan sebagai pegangan hidup. Meskipun bernilai lokal tetapi nilai yang terkandung di dalamnya dianggap sangat universal. 26

Sementara Moendardjito mengatakan bahwa unsur budaya daerah potensial sebagai local genius karena telah teruji kemampuannya untuk bertahan sampai sekarang. Adapun ciri-ciri budaya daerah sebagai local genius adalah: (1) mampu bertahan terhadap budaya luar, (2) memiliki kemampuan mengakomodasi unsur-unsur budaya luar, (3) mempunyai kemampuan mengintegrasikan unsur budaya luar ke dalam budaya asli, (4) mempunyai kemampuan mengendalikan, dan (5) mampu memberi arah pada perkembangan budaya. ${ }^{27}$

\section{Deradikalisasi Islam melalui Pendidikan Multikultural Berbasis Kearifan Lokal pada Masyarakat Cigugur}

Masyarakat Cigugur secara umum merupakan masyarakat yang mempelajari dan bahkan mewarisi ajaran Madraisme. Secara garis besar, ajaran Madraisme menekankan pengabdian kepada Tuhan dan menjunjung tinggi nilai-nilai perikemanusiaan. Tujuan manusia menurut ajaran Madraisme adalah "sampurnaning hirup, sajatining mati" yang berarti mencapai kesempurnaan hidup dan mencapai kematian yang sejati. Untuk itu, Madraisme mendorong pengikutnya untuk mengarahkan seluruh perbuatannya untuk menjalankan perintah Tuhan. Untuk itu, para pengikut Madraisme didorong untuk senantiasa menilai diri sendiri apakah perilakunya sudah selaras dengan perintah Tuhan dan hakikat kemanusiaan atau belum. Dalam usaha untuk mengukur keselarasan tersebut

26 Ayatrohaedi, Kepribadian Budaya Bangsa: local Genius (Jakarta: Pustaka Jaya, 2009), 18-19.

27 Ibid., 40-41. 
manusia harus menggunakan sir-rasa-pikir, yakni kehendak, perasaan, dan pikiran, sehingga agama akan menjadi urat nadi dan nafas kehidupan.

Banyak sekali idiom-idiom dalam ajaran Madraisme yang diambil dari ajaran Islam, selain juga banyak menyerap unsur-unsur budaya lokal. Misalnya penggunaan istilah iman dalam konsep iman kana tanah, penggunaan istilah kiblat dalam konsep ngiblating ratu raja, maupun ajaran-ajaran substantive lainnya. Pada dasarnya Kyai Madrais, yang merupakan penyederhanaan penyebutan dati Kyai Muhammad Rais, merupakan sosok yang lahir dari keluarga muslim, bahkan beberapa sumber menerangkan bahwa Kyai Madrais berasal dari keluarga bangsawan kesultanan Cirebon. Melihat asal-usul seperti itu, bisa dimengerti jika ajaran agama Islam memberikan pengaruh yang besar terhadap Kyai Madrais dan paham Madraisme itu sendiri.

Proses historis telah menunjukkan terjadinya perubahan yang sangat mendasar pada para pengikut Madraisme. Perlu dicatat bahwa pada awalnya para pengikut ajaran Kyai Madrais merupakan para pemeluk Islam dengan implementasi ajaran agama yang dikombinasi dengan unsur-unsur budaya lokal. Sementara sekarang ini, para pengikut Madraisme tersebut telah berkembang sebagai masyarakat yang multi agama. Perkembangan ini menempatkan masyarakat Cigugur menjadi semakin unik, yakni masyarakat yang multi agama dan multi kultural. Dalam hubungan ini, prinsip-prinsip ketuhanan dan kemanusiaan yang diajarkan oleh Kyai Madrais justru menjadi perekat di tengah-tengah perbedaan yang ada. Bahwa Kyai Madrais sejak awal memang mengajarkan sikap toleran terhadap agama dan kepercayaan orang lain, sekaligus selalu berpegang teguh pada watak atau nilai-nilai kepribadian yang diwarisi secara turun temurun. 
Paham Madraisme memiliki perspektif tersendiri menyangkut pendidikan. Bahwa pendidikan perlu dilakukan secara menyeluruh, terpadu, dan terus menerus mengikuti siklus kehidupan. Secara anatomis, sistem pendidikan yang diselenggarakan oleh pengikut paham Madraisme dapat dijelaskan dalam tiga dimensi, yakni dimensi waktu, dimensi tempat, dan dimensi isi dengan penjelasan sebagai berikut.

\section{Dimensi waktu penyelenggaraan pendidikan}

Terinspirasi oleh kehidupan yang tidak kurang sebagai suatu rantai perjalanan panjang yang berkesinambungan dari generasi pendahulu menuju generasi penerus, maka pendidikan diselenggarakan dalam tiga fase, yakni: sateuacan nitis (sebelum nitis), sateuacan boboran (sebelum lahir), saatosna boboran (setelah lahir).

Pendidikan sebelum nitis (sateuacan nitis) bisa dianalogikan sebagai pendidikan pranikah, yakni dilakukan kepada kaum lelaki dan kaum wanita dewasa sebelum menikah. Pendidikan pranikah ini dimaksudkan untuk memastikan bahwa calon-calon mempelai merupakan pribadi-pribadi yang benar, yakni pribadipribadi religius yang ingin menjalani kehidupan yang benar (sejatining urip) dan ingin memperoleh kematian yang benar (sejatining mati). Kehidupan yang benar dan kematian yang benar hanya bias dicapai jika tiap-tiap pribadi memiliki komitmen untuk melaksanakan perintah Tuhan dan menjauhi larangan Tuhan. Pribadi-pribadi seperti inilah yang sanggup menjaga hubungan baik dengan Tuhan, menjaga hubungan baik dengan sesama manusia, dan menjaga hubungan baik dengan sesama makhluk. Inilah indikator pribadi yang berkualitas menurut ajaran Madraisme. Pribadi yang berkualitas seperti inilah yang memungkinkan untuk memiliki benih-benih kehidupan yang baik, yakni calon-calon generasi penerus yang unggul, 
sesuai dengan kehendak Tuhan. Pribadi-pribadi yang baik, dengan benih-benih yang baik, jika saling berjodoh akan melahirkan generasi-generasi kehidupan yang baik. Inilah hakikat pendidikan sebelum nitis (sateuacan nitis) menurut konsepsi Madraisme. 28

Pendidikan sebelum lahir (sateuacan boboran), merupakan pendidikan yang diberikan kepada janin saat masih berada di dalam kandungan. Pendidikan sebelum lahir (sateuacan boboran) terutama dilakukan oleh sepasang suami-istri yang merupakan orang tua dari janin tersebut, meskipun lingkungan sekitar secara umum juga berpengaruh terhadap perkembangan sang janin. Secara umum, pendidikan sebelum lahir (sateuacan boboran) dilakukan dengan memberikan lingkungan yang baik, mulai dari pikiran, ucapan, hingga perilaku yang baik. Menurut paham Madraisme, jika selama di dalam kandungan sang janin mendapat lingkungan yang baik, berupa pikiran, ucapan, dan perilaku yang baik, maka jika terlahir kelak akan menjadi generasi baru yang baik pula. ${ }^{29}$

Pendidikan setelah lahir (saatosna boboran) adalah pendidikan yang diberikan kepada seluruh anak manusia setelah terlahir di dunia hingga menginjak pada jenjang kedewasaan. Setiap orang tua harus memikul tangung jawab untuk memberikan pendidikan kepada anakanaknya. Akan tetapi karena adanya berbagai keterbatasan, baik dalam hal waktu, tenaga, maupun wawasan, maka pelaksanaan pendidikan setelah lahir (saatosna boboran) tidak sekedar berada di rumah, melainkan juga di sekolah maupun di lingkungan masyarakat. ${ }^{30}$

${ }^{28}$ Wahyu dan Emon Radiman, Wawancara, 4 Oktober 2015.

${ }^{29}$ Ibid.

${ }^{30}$ Ibid. 


\section{Dimensi tempat penyelenggaraan pendidikan}

Berdasarkan penjelasan dia atas, tampaknya pendidikan setelah lahir (saatosna boboran) dalam ajaran Madraisme sejalan dengan konsepsi tri pusat pendidikan sebagaimana yang dikembangkan oleh $\mathrm{Ki} H a j a r$ Dewantoro, yakni pendidikan di lingkungan keluarga (pendidikan informal), pendidikan di sekolah (pendidikan formal), dan pendidikan di lingkungan masyarakat (pendidikan nonformal). Dengan demikian, dimensi tempat penyelenggaraan pendidikan pada masyarakat Cigugur, yang nota bena merupakan penganut paham Madraisme, perlu dianalisis berdasarkan konsepsi tri pusat pendidikan tersebut.

Pertama, pendidikan di lingkungan keluarga (pendidikan informal). Potret multikulturalitas masyarakat Cigugur tidak saja terlihat pada lingkup kelurahan, melainkan juga terlihat pada lingkup keluarga. Sebagai misal, Pangeran Djatikusuma yang merupakan cucu dari Kyai Madrais, memiliki 8 (delapan) putra-dan putri dengan agama yang berbeda-beda, yakni: 1 (satu) orang beragama Islam, 1 (satu) orang beragama Protestan, 1 (satu) orang beragama Katolik, sedangkan 5 (lima) orang lainnya merupakan penganut Sunda Wiwitan. Tidak sedikit keluarga pada masyarakat Cigugur yang multi agama, tetapi dapat menjalankan kehidupan secara rukun. Salah satu faktor penting bagi terciptanya kerukunan adalah pendidikan yang terus-menerus dilakukan di lingkungan keluarga, yakni penanaman tentang pentingnya memupuk sikap saling menghormati, saling menghargai, dan toleran terhadap satu sama lain. ${ }^{31}$

Kedua, pendidikan di lingkungan sekolah (pendidikan formal). Kesadaran bersekolah pada masyarakat Cigugur terbilang tinggi. Hal ini ditunjukkan oleh adanya beberapa

${ }^{31}$ Ibid. 
lembaga pendidikan dasar dan menengah yang didirikan oleh lembaga-lembaga swadaya masyarakat yang ada, baik yang dilakukan oleh masyarakat Muslim dengan mendirikan pondok pesantren, masyarakat Kristen dengan menyelenggarakan pendidikan di lingkungan gereja, maupun sekolah-sekolah negeri yang didirikan oleh pemerintah. Lembaga-lembaga pendidikan formal tersebut tumbuh dan berkembang dengan baik, tanpa sedikitpun mengindikasikan adanya konflik.

Ketiga, pendidikan yang diselenggarakan di lingkungan masyarakat (pendidikan nonformal), salah satunya adalah yang dilaksanakan di lembaga adat karuhun urang (AKUR) yang berpusat di Paseban. Dalam hal ini, para pini sepuh, yakni para tokoh adat yang dituakan menyampaikan pesan-pesan moral yang dijadwalkan secara rutin tiap minggu. Materi utama yang disampaikan di Paseban terutama menyangkut nilai-nilai kearifan lokal yang berhubungan dengan: (1) pembinaan hubungan manusia dengan Tuhan, (2) pembinaan hubungan manusia dengan sesama manusia, dan (3) pembinaan hubungan manusia dengan lingkungan sekitar.

Dalam rangka menanamkan budi luhur terhadap pengikut paham Madraisme, dilakukan pertemuanpertemuan dan upacara-upacara, di antaranya dengan menjadikan tanggal 1 Sura (tahun baru bagi masyarakat Islam di Jawa dan Sunda) sebagai hari raya bagi penganut Madraisme. Pada setiap sarasehan, diajarkan dan ditanamkan ajaran budi luhur. Pengajaran disampaikan melalui ceramah oleh para pini sepuh dilanjutkan dengan diskusi di antara peserta.

\section{Dimensi isi pendidikan}

Ajaran Madraisme sangat menekankan etika sebagai pedoman dan tuntunan dalam berperilaku sosial. Adapun pedoman dan tuntunan berperilaku sosial tersebut berupa 
cara ciri manusia dan cara ciri bangsa. Dalam konteks tersebut, cara adalah ketentuan perilaku hidup, sedangkan ciri adalah perwujudan sifat.

Cara ciri manusia terdiri dari lima unsur, yakni: (1) welas asih, (2) undak-unik, (3) tata krama, (4) budi daya dan budi basa, serta (5) wiwaha yudha negara. Welas asih merupakan suatu hal yang menjadi cara-ciri manusia. Bila kita berbicara berperikemanusiaan berarti di dalamnya berisi rasa kasih (welas asih yang memancar dari budi luhur). Undak unik pada dasarnya merupakan penghormatan terhadap adanya suatu tingkatan dan sebutan terhadap tingkatan tersebut. Misalnya salam susunan keluarga, ada sebutan yang menunjukkan perbedaan seperti: kakek, nenek, bapak, ibu, anak, kakak, adik, cucu, buyut, kemenakan, dan sebagainya. Manusia perlu menyadari adanya undak unik, yakni adanya tingkatan dan sebutan, sekaligus cara bersikap yang baik terhadap tingkatan dan sebutan tersebut.

Tata Krama. Adanya undak unik dalam kehidupan masyarakat mengharuskan kita untuk mengenal tata krama atau etika. Tata artinya aturan dan krama berarti pergaulan. Jadi tata krama merupakan tatanan dalam pola kehidupan bermasayarakat demi terciptanya kehidupan masyarakat manusia yang tenteram, damai dan terwujudnya saling hormat menghormati, harga menghargai di antara sesama manusia. Dengan itu, akan tercipta kerukunan hidup baik dalam keluarga, bermasyarakat maupun bernegara. Budi daya dan budi basa pada dasarnya merupakan apa yang dikatakan jiwa dari tata krama. Manusia adalah makhluk yang berbudi. Budi daya budi basa dimaksudkan untuk pengendalian diri. Wiwaha Yuda Negara mengandung pengertian yang luas. Wiwaha berarti pertimbangan, yuda berarti perang, nagara berarti diri kita sendiri. Wiwaha yuda negara berarti kesadaran sebagai manusia untuk berbudi luhur, bahwa 
dalam melaksanakan gerak hati dan pikiran harus memakai pertimbangan dan memerangi rasa dan pikir pada saat keduanya dipengaruhi oleh sifat-sifat di luar sifat kemanusiaan.

Model pendidikan sebagaimana yang dikonsepsikan dan diaktualisasikan dalam kehidupan masyarakat Cigugur seperti di atas tampaknya cukup efektif sebagai model deradikalisasi Islam. Sebagai masyarakat yang multikultural, tentu dalam kehidupan masyarakat Cigugur pernah terjadi konflik antaragama. Akan tetapi konflik tersebut dengan cepat dapat diantisipasi dan/atau diterapi mengingat adanya adanya kearifan lokal berupa sistem pendidikan yang bersifat menyeluruh, terpadu, dan terus menerus mengikuti siklus kehidupan. Dengan demikian, deradikalisasi sebagaimana yang terjadi pada masyarakat Cigugur dapat dilihat dari dua sudut pandang. Pertama, deradikalisasi sebagai langkah antisipasi sebelum terjadinya radikalisasi itu sendiri. Kedua, deradikalisasi sebagai strategi terapi terhadap kecenderungan berkembangnya radikalisme. ${ }^{32}$

Sebagai masyarakat yang bersifat terbuka, terlebih didukung oleh kecanggihan teknologi informasi dan komunikasi, tentu tidak menutup kemungkinan bagi masyarakat Cigugur untuk bersentuhan dengan anasiranasir paham radikal. Oleh karena itu diperlukan formula antisipatif terhadap anasir-anasir radikalisme yang terdapat dalam kehidupan masyarakat Cigugur. yakni melalui pendidikan multikultural berbasis kearifal local sebagaimana dijelaskan di atas. Model pendidikan multikultural berbasis kearifal lokal pada masyarakat Cigugur terbukti memiliki daya antisipatif yang tinggi

32 Abu Rokhmad, "Radikalisme Islam dan Upaya Deradikalisasi Paham Radikal," Walisongo 20, no. 1 (Mei 2012): 107. 
dalam mencegah berkembangnya paham radikalisme. Di samping itu, model pendidikan multikultural berbasis kearifal lokal pada masyarakat Cigugur tersebut sekaligus juga cukup efektif sebagai model strategi terapi yang bersifat sosio-kultural manakala konflik antaragama terjadi, mengingat model pendidikan multikultural berbasis kearifal lokal pada masyarakat Cigugur telah melahirkan masyarakat Islam yang toleran dan cinta damai (rahmatan lil'alamin).

Hubungan antara model pendidikan multikultural berbasis kearifal lokal pada masyarakat Cigugur dengan deradikalisasi Islam dapat dijelaskan dalam dua tahapan sebagai berikut. Pertama, deradikalisasi dilakukan sedini mungkin dengan melakukan langkah pencegahan terhadap anasir-anasir paham radikal (preventive deradicalization). Kedua, deradikalisasi dilakukan melalui pemeliharaan pemahaman Islam yang rahmatan lil'alamin (preservative deradicalization). ${ }^{33}$

\section{E. Penutup}

Sebagai penutup artikel ini, penulis menggarisbawahi perspektif paham Madraisme tentang pendidikan yang dilakukan secara menyeluruh, terpadu, dan terus menerus mengikuti siklus kehidupan, yang mencakup tiga dimensi, yakni dimensi waktu, dimensi tempat, dan dimensi isi dengan penjelasan sebagai berikut.

Menurut dimensi waktu, pendidikan diselenggarakan dalam tiga fase. Pertama, sateuacan nitis (sebelum nitis) yang dapat dianalogikan dengan pendidikan untuk memastikan bahwa calon-calon mempelai merupakan pribadi-pribadi yang benar dan religius sehingga dapat menjalani kehidupan yang benar (sejatining urip). Kedua, sateuacan boboran (sebelum lahir), yakni merupakan pendidikan yang

${ }^{33}$ Ibid. 
diberikan kepada janin saat masih berada di dalam kandungan dengan harapan jika terlahir kelak akan menjadi generasi baru yang baik. Ketiga, saatosna boboran (setelah lahir), yakni yakni diberikan kepada seluruh anak manusia setelah terlahir di dunia hingga menginjak pada jenjang kedewasaan. Pelaksanaan pendidikan setelah lahir (saatosna boboran) tidak sekedar berada di rumah, melainkan juga di sekolah maupun di lingkungan masyarakat.

Menurut dimensi tempat, masyarakat Cigugur menyelenggarakan pendidikan di lingkungan keluarga (pendidikan informal), lingkungan sekolah (pendidikan formal), dan lingkungan masyarakat (pendidikan nonformal). Tidak sedikit keluarga pada masyarakat Cigugur yang multi agama, tetapi dapat menjalankan kehidupan secara rukun. Salah satu faktor penting bagi terciptanya kerukunan adalah pendidikan yang terusmenerus dilakukan di lingkungan keluarga, yakni penanaman tentang pentingnya memupuk sikap saling menghormati, saling menghargai, dan toleran terhadap satu sama lain. Sementara, pendidikan di lingkungan sekolah dan di lingkungan masyarakat yang diberikan oleh para tokoh adat dan para pini sepuh dengan menanamkan pesan-pesan moral yang digali dari nilai-nilai kearifan lokal yang ada.

Menurut dimensi ini, ajaran Madraisme sangat menekankan etika sebagai pedoman dan tuntunan dalam berperilaku sosial. Adapun pedoman dan tuntunan berperilaku sosial tersebut berupa cara ciri manusia dan cara ciri bangsa. Dalam konteks tersebut, cara adalah ketentuan perilaku hidup, sedangkan ciri adalah perwujudan sifat. Cara ciri manusia terdiri dari lima unsur, yakni: (1) welas asih, (2) undak-unik, (3) tata krama, (4) budi daya dan budi basa, serta (5) wiwaha yudha negara. Sedangkan cara-ciri bangsa mencakup lima unsur, yaitu: (1) rupa, (2) bahasa, (3) adat, (4) aksara, dan (5) kebudayaan. Pada dasarnya 
cara-ciri manusia dan cara-ciri bangsa menekankan nilai-nilai kemanusiaan dan nilai-nilai kebangsaan di atas dasar nilainilai religius.

Melalui model pendidikan multikultural berbasis kearifal local, maka masyarakat Cigugur dapat melakukan deradikalisasi Islam dalam dua tahapan, yakni: (1) deradikalisasi dilakukan sedini mungkin dengan melakukan langkah pencegahan terhadap anasir-anasir paham radikal (preventive deradicalization), dan deradikalisasi dilakukan melalui pemeliharaan pemahaman Islam yang rahmatan lil'alamin (preservative deradicalization), sehingga berkembang masyarakat Islam yang toleran dan cinta damai (rahmatan lil'alamin)[.]

\section{REFERENSI}

Arkoun, Mohammed. Islam Kontemporer menuju Dialog Antaragama. Yogyakarta: Pustaka Pelajar, 2001. Ayatrohaedi. Kepribadian Budaya Bangsa: local Genius. Jakarta: Pustaka Jaya, 2009.

Azra, Azumardi. "Radikalisme Islam Indonesia." Tempo. 15 Desember 2002.

Azra, Azyumardi. Pergolakan Politik Islam; dari Fundamentalisme, Modernisme hingga Post-Modernisme. Jakarta: Paramadina, 1996.

Banks, James A. An Introduction to Multicultural Education. Boston: Allyn and Bacon, 1993.

F. X. Rahyono. Kearifan Budaya dalam Kata. Jakarta: Wedatama Widyasastra, 2009.

H.A.R Tilaar. Kekuasaan dan Pendidikan: Manajemen Pendidikan Nasional dalam Pusaran Kekuasaan. Jakarta: Rineka Cipta, 2009.

James A Banks dan Cherry A. McGee Banks. "Multicultural Education: Historical Development, Dimensions, and 
Practice." In Handbook of Research on Multicultural Education, n.d.

K.M, Saini. "Kearifan Lokal di Arus Global." Pikiran Rakyat, 30 Juli 2005.

Mahfud, Choirul. Pendidikan Multikultural. Yogyakarta: Pustaka Pelajar, 2006.

Mubarak, M. Zaki. Geneologi Islam Radikal di Indonesia. Jakarta: LP3ES, 2008.

Muhammad Hisyam, dkk. Islam dan Radikalisme di Indonesia. Jakarta: LIPI Press, 2005.

Naritoom, Chatcharee. "Local Wisdom/Indigenous

Knowledge System." Kasetsart University, Thailand, 18

Maret 2015. http://pimd.iwmi.org/Library/pdf/PPT

6 Indigeneous Knowledge Systems.ppt.

Nasution, Harun. Islam Rasional. Bandung: Mizan Media Utama, 1995.

Ridwan, Nurma Ali. "Landasan Keilmuan Kearifan Lokal." Ibda: Jurnal Studi Islam dan Budaya P3M STAIN Purwokerto 5, no. 1 (Juni 2007).

Robertson, Roland. "Religion in Java: Conflict and Integration." In Sociology of Religion: Selected Readings. England: Penguine Book, 1971.

Rokhmad, Abu. "Radikalisme Islam dan Upaya Deradikalisasi Paham Radikal." Walisongo 20, no. 1 (Mei 2012).

Santoso, Listiyono. Seri Pemikiran Tokoh Epistimologi Kiri. Jakarta: Ar-Ruzz Media, 2010.

Tarmizi Taher, et.all. Radikalisme Agama. Jakarta: PPIM IAIN Syarif Hidayatullah, n.d.

Taruna, Dody S. Pendidikan Agama Islam Berwawasan Multikulturalisme. Jakarta: Kementrian Agama RI, 2010. Turmudi, Endang, ed. Islam dan Radikalisme di Indonesia. Jakarta: LIPI Press, 2005.

Wahyu, dan Emon Radiman. Wawancara, 4 Oktober 2015. 
